\title{
Kidney function in primary nephrotic syndrome with insulin resistance
}

\author{
Jiaping Jin • Aihua Zhang
}

Received: 24 September 2012 / Accepted: 8 October 2012 / Published online: 6 November 2012

(C) IPNA 2012

Dear Sirs,

We read the response to our article on insulin resistance in children with primary nephrotic syndrome and normal renal function by Sexton and colleagues with great interest [1]. Sexton et al. demonstrated that glycosylated hemoglobin levels (HBA1c) did not correlate with estimated glomerular filtration rate (eGFR) in adult primary nephrotic syndrome patients without diabetes mellitus [1].

We previously reported that fasting serum C-peptide in children with primary nephrotic syndrome was negatively associated with GFR according to the Schwartz formula using serum creatinine [2]. We calculated eGFR using the new CKD-EPI-CysC equation- $\mathrm{eGFR}=127.7 \times \mathrm{CysC}^{-1.17} \times$ age $^{-0.13} \times 0.91$ (if female) - using serum cystatin C [3] and then compared these new eGFR values with the GFR calculated with the Schwartz formula using serum creatinine. The GFR estimated by the Schwartz equation was significantly higher than the eGFR according to the new CKD-EPI-CysC equation, both in normal controls and in children with primary nephrotic syndrome $(P<0.0001)$. There was no significant difference in the eGFRs estimated using the new CKD-EPI-CysC formula between patients $\left(117.83 \pm 2.68 \mathrm{ml} / \mathrm{min} / 1.73 \mathrm{~m}^{2}\right)$ and controls $\left(112.31 \pm 2.05 \mathrm{ml} / \mathrm{min} / 1.73 \mathrm{~m}^{2}\right)$. Similarly, no differences were observed between nephritic $\left(110.59 \pm 6.35 \mathrm{ml} / \mathrm{min} / 1.73 \mathrm{~m}^{2}\right)$ and simple $\left(119.56 \pm 2.94 \mathrm{ml} / \mathrm{min} / 1.73 \mathrm{~m}^{2}\right)$ type nephrotic syndrome, or among steroid-sensitive $(121.15 \pm 3.37 \mathrm{ml} / \mathrm{min} /$

\section{J. Jin $\cdot$ A. Zhang $(\square)$}

Department of Nephrology,

Nanjing Children's Hospital, Nanjing Medical University, 72 Guangzhou Road,

Nanjing 210029 Jiangsu Province, People's Republic of China

e-mail: zhaihua@njmu.edu.cn $\left.1.73 \mathrm{~m}^{2}\right)$, steroid-resistant $\left(102.89 \pm 6.42 \mathrm{ml} / \mathrm{min} / 1.73 \mathrm{~m}^{2}\right)$, and steroid-dependent $\left(108.74 \pm 7.35 \mathrm{ml} / \mathrm{min} / 1.73 \mathrm{~m}^{2}\right)$ patients. Moreover, there were no significant differences in eGFR calculated using the new CKD-EPI-CysC equation between a high HOMA-IR (homeostatic model assessment index of insulin resistance) group (HOMA-IR $>0.77$ ) and a low HOMAIR group (HOMA-IR $<0.77 ; 111.90 \pm 4.30 \mathrm{ml} / \mathrm{min} / 1.73 \mathrm{~m}^{2} \mathrm{vs}$ $121.58 \pm 3.37 \mathrm{ml} / \mathrm{min} / 1.73 \mathrm{~m}^{2}$ respectively, $P=0.079$ ) or between the high C-peptide group (C-peptide $>0.37 \mathrm{ng} / \mathrm{ml}$ ) and the low C-peptide group (C-peptide $<0.37 \mathrm{ng} / \mathrm{ml} ; 114.90 \pm$ $3.28 \mathrm{ml} / \mathrm{min} / 1.73 \mathrm{~m}^{2}$ vs $124.45 \pm 4.47 \mathrm{ml} / \mathrm{min} / 1.73 \mathrm{~m}^{2}$ respectively, $P=0.101$ ).

Our data indicate discrepancies between eGFR using the new CKD-EPI-CysC equation and GFR using the Schwartz formula. Although $\mathrm{Cys} C$ has been employed more widely as a marker of GFR, it could be influenced by serum albumin [3]. It has been reported that patients with nephrotic syndrome present lower CysC levels [3]. Therefore, further validation is needed in children with nephrotic syndrome using standard techniques to compare measurements of GFR.

\section{References}

1. Sexton DJ, Eustace JA (2012) Insulin resistance in primary nephrotic syndrome; is kidney function normal? Pediatr Nephrol. doi:10.1007/ s00467-012-2343-1

2. Jin J, Jin B, Huang S, Yuan Y, Ding G, Bao H, Chen Y, Han Y, Zhao F, Zhang A (2012) Insulin resistance in children with primary nephrotic syndrome and normal renal function. Pediatr Nephrol 27:1901-1909

3. Hofstra JM, Willems JL, Wetzels JF (2011) Estimated glomerular filtration rate in the nephrotic syndrome. Nephrol Dial Transplant 26:550-556 